\title{
The Influence of Message Framing on Experiential and Material Purchase: The Mediating Role of Perceived Value
}

\section{Bin Li ( $\nabla$ bingoli@jnu.edu.cn )}

Jinan University https://orcid.org/0000-0001-5363-0776

Li Lei

Jinan University

Kaidi Zhang

Jinan University

Haiying Wei

Research Institute on Brand Innovation and Development of Guangzhou

Aimei Li

Jinan University

\section{Research Article}

Keywords: material purchase, experiential purchase, message framing, perceived value, purchase intention

Posted Date: March 1st, 2022

DOI: https://doi.org/10.21203/rs.3.rs-1198617/v1

License: (c) (i) This work is licensed under a Creative Commons Attribution 4.0 International License. Read Full License 


\section{Abstract}

Experiential advantage literature suggests that experiential purchase could make consumer happier and made a recommendation of experience than material purchase. However, most research has focused on the effect of these two types of purchases on their consequences, which ignore the antecedent factors that affect consumers' consumption decision making. This study discusses when and why would consumers prefer to experiential purchase or material purchase. We test if message framing (such as promotion and prevention) would affect differential types of purchases' consumption intention or not. In Study 1 , participants in prevention condition perceived higher value of material purchase than experiential purchase, then caused they chose material purchase in preference to experiential purchase. In Study 2, participants in the promotion condition perceived higher value of experiential purchase than material purchase, then caused they chose experiential purchase in preference to material purchase. Results suggest that message framing would affect differential types of purchases' consumption intention through their perceived value.

\section{Introduction}

With the development of social economy, people are no longer satisfied with material needs, but try to pursuit for satisfied with spiritual needs. Most people begin to spend money pursuing special experiences, such as travel, extreme sports and so on, which called experiential purchases. Experiential purchases are those made with the primary intention of acquiring a life experience; while material purchases are those made with the primary intention of acquiring a material good(Van Boven \& Gilovich, 2003). It's suggested that consumers should make a more experiential consumption and less material consumption, that is the experience recommendation, which was based on the reported experiential advantage that experiential purchases made consumers happier than material purchases (Caprariello \& Reis, 2013; Carter \& Gilovich, 2014; Gilovich et al., 2015; Howell \& Hill, 2009; Kumar \& Gilovich, 2016; Weingarten \& Goodman, 2021). However, most experiential advantage literature has focused on the effect of these two types of purchases on their consequences, such as well-being and envy, which ignore the factors that affect consumers' consumption decision making(Kumar \& Gilovich, 2016; Gilovich \& Gallo, 2020; Yu et al., 2016; Lin et al., 2018). As there are so many merchandises in stores, people have no idea what to choose, sometimes. Therefore, it is particularly important for stores to advertise different products to consumers, which could further improve their willingness to buy(Dehghani \& Tumer, 2015; Martins et al., 2019). To contribute to the experiential advantage argument, our study will enrich this literature from two perspectives.

First, there is a significant difference between the experiential purchase and material purchase in happiness; while other differences between the two purchases, especially the differences between advertising and promotions are still unclear (Gilovich et al., 2015; Aknin et al., 2018). As we all know, consumption is an important factor to promote economic growth. Therefore, how to enhance consumers' purchase intention and promote shopping, are both important for companies and economies. So we choose purchase intention as the outcome variable, to find the ways to enhance people's willingness to buy, as well as the differences in the ways between the two purchases. 
Second, the relationships between message framing and purchase intention have been repeatedly reported in psychology literature(Meyerowitz \& Chaiken, 1987a; Chen et al., 1998; Gamliel \& Herstein, 2007; Zhang et al., 2018; Tanford et al., 2019). Surprisingly, the experiential advantage literature has not investigated the roles of message framing. Gallo et al.(2017) find consumers rely more on intuition when making experiential purchase decisions, while they rely more on deliberation, when making material purchase decisions. Furthermore, dual-process theory is the classic theory of message framing (Guo et al., 2017). Therefore, message framing may be an import factor to influence consumers' willingness to buy material and experiential purchases. This study seeks to explore the interaction of purchase type and message framing on purchase intention, as well as the underlying mechanism. Uncovering this underlying mechanism could empower marketers to match the advertising with consumption types better.

Through two studies with consumers in China, our research attempts to contribute to the experiential purchase literature by (1) incorporating purchase intention to the experiential advantage model; (2) proposing an interaction factor of message framing on purchase intention.

\section{LITERATURE REVIEW AND HYPOTHESE DEVELOPMENT}

\section{Message framing and differential types of purchase decision making}

According to Van Boven and Gilovich (2003), experiential purchase refers to what we do, while material purchase refers to what we have, and the former leads to greater well-being than the latter, which is called the experience recommendation. Even the same objects described as experiential purchases would be more satisfied than described as material purchase(Mann \& Gilovich, 2016). There are three underlying reasons for this. First, experiential purchases could enhance social relations more effectively than materials; furthermore, a bigger part of consumers' identity was formed by experience not objects; last, they evoke fewer social comparisons than material purchases(Gilovich et al., 2015). Experiential purchase could arouse not only stronger positive emotions than material purchases, but also stronger negative emotions(i.e. envy)(Lin, 2018; Lin et al., 2018). They incite a more benign envy than materials; while materials incite more malicious envy than them(Lin, 2018). Besides, experiential purchase has an advantage over material purchase in marketing. It is found that consumers are eager to make experiential consumption first and make material consumption later (Hwang et al., 2019). Even though they don't have enough money, they are more willing to borrow for experiences rather than materials(Tully \& Sharma, 2017). Furthermore, consumers would be more patient when waiting for experiential consumption than material consumption(Kumar et al., 2014). After consumption, people prefer to talk about experiences over materials with their friends, which contribute to the spread of the word of mouth of experiential purchases (Duan \& Dholakia, 2018; Gannon et al., 2019).

The research on experiential consumption and material consumption mainly focuses on the consequence variables, which ignore the factors that promote consumers to make experiential purchases or material purchases. Experiential consumption is made for experiencing, which tend to meet the psychological needs of consumers; while material consumption is made for possessing, tend to meet the physical needs of consumers. It's difficult to say what kind of consumption person would prefer because consumers have so 
many different needs, psychological or physical. However, researchers do find the processing of consumer affects their choice of consumption: consumption intention of experiential purchase would be stronger than material purchase in the intuition condition but weaker in the rationality condition (Gallo et al., 2017). Consumption intention is the willingness of consumers to buy products, in other words, it's the likelihood the buyer intends to buy the product (Grewal et al., 1998). Therefore, we believe that there is no significant difference between the experiential consumption intention and material consumption intentions in general, but once the processing of consumption was priming differently, the distinction of intention between two consumption would be clear.

Message framing refers to the effect that people respond differently to different descriptions (in positive or negative description) of the same question, which has been demonstrated in marketing and health research(Chen et al., 1998; Van't Riet et al., 2016). Message framing could change people's attitude, purchase intention and behavior (Baek \& Yoon, 2017; Amatulli et al., 2019; Lagomarsino et al., 2020). The persuasion of the message framing is inconsistent. Sometimes, the message will be more persuasive in the promotion conditions, while the situation may be reversed, it will be more persuasive in the prevention condition(Maheswaran \& Meyers Levy, 1990; Gallagher \& Updegraff, 2012; Baek \& Yoon, 2017; Amatulli et al., 2019; Lagomarsino et al., 2020). Researchers believe that promotional messages would be more effective in promoting safe behaviors that serve to prevent illness, while preventive information would be more effective to promote risky behaviors(Meyerowitz \& Chaiken, 1987b; Van't Riet et al., 2016). The framing effect will be affected by involvement, time pressure, personality characteristics, the way of processing and so on(Maheswaran \& Meyers Levy, 1990; Zhang \& Buda, 1999; Ülkümen \& Thomas, 2013; Guo et al., 2017).

According to dual-processing theory, there are two systems of processing which including analytical/ systematic and heuristic/ holistic systems(McElroy \& Seta, 2003). Analytical processing is relatively slow, controlled, and effortful, while heuristic processing is relatively quick, automatic, and easy(Inbar et al., 2010). Confronting with choices, people act as "cognitive misers" and tend to decide intuitively at first, then to adjust rationally (Sun et al., 2007). Compared to gain, consumer will pay more attention to loss, that is, the inclination of loss aversion(Tversky \& Kahneman, 1992). Therefore, consumers tend to depend on intuition in the promotional conditions when deciding what to buy and rely on reason in the prevention condition. To some extent, purchase intention of consumer depends on the processing style of message. However, different types of consumption have different advantages under different processing styles, as mentioned in the front(Gallo et al., 2017). So, there may be an interaction of consumption type and message framing on purchase intention. Experiential purchase is what we buy for experience, and material purchase is what we buy for possession. The latter is tangible, while the former is intangible, could only keep in memory. It is harder to evaluate experiential purchase objectively. Inbar et al. (2010) find when choices are seen as evaluable objectively, people elicit a preference for choosing rationally. In other words, consumer will choose experiential purchases intuitively, and choose material purchase rationally.

Processing promotional messages, people depend more on intuition causing an advantage of experiential purchase over materials; meanwhile, processing preventive message, they depend more on reason causing an advantage of material purchase. Thus, we hypothesize the following, 
H1: There will be an interaction effect of consumption type and message framing on purchase intention. Experiential purchases will have a greater impact on consumers' purchase intention in promotion condition, but less impact on consumers' purchase intention in prevention condition than material purchases.

\section{Mediating role of perceived value}

Perceived value refers to the overall assessment of the utility of products or service based on perceptions of what is received and what is given (Zeithaml, 1988). Perceived value is an important predictor of consumers' purchase intention(Tam, 2004; Kuo et al., 2009; Pandža Bajs, 2015; Konuk, 2018). When consumers consider which to choose, they will evaluate the value of products at first and make a decision on the principle of value maximization. The perceived value of products is more important than objective value when consumers make buying decisions (Zeithaml, 1988). The same product has different meanings to different people, so does its perceived value. For example, a handbag of Hermès, to someone, is the symbol of status, with high perceived value; while it's just an ordinary handbag to other people with low perceived value. Consumers tend to choose products or service with highest perceived value. Additionally, the description of consumption would affect the perceived value of products or service (Chen et al., 1998; Grewal et al., 1998; Banerjee \& Bandyopadhyay, 2003). Emphasizing the benefits or losses of consumption will activate different processing styles of consumer, which further impacts the perceived value of consumption. That is to say, the perceived value will be affected by purchase type and message framing.

People tend to avoid loss(Tversky \& Kahneman, 1992), so they may pay more attention to preventive information and adopt analytical processing on prevention conditions. When selecting materials, people tend to compare and evaluate the objects, then make a choice on reason(Inbar et al., 2010), which has an advantage under analytical processing conditions. So, the perceived value of material purchase will be higher in preventive condition than in promotional condition, and it further influences the purchase intention of consumers. However, when selecting experience, which is difficult to evaluate objectively, people rely more on their intuition and adopt heuristic processing. At this time, if we push them to prevention information and force them to think about the loss rationally, the appeal of experiential buying will decrease. It's easy to infer that the perceived value of experiential purchase will be lower in preventive condition than in promotional condition, which will further influence the consumption intention. Overall, there is a match of processing style between purchase type and message framing. In most occasions, consumer chooses experiential purchases intuitively, and choose material purchases rationally. Adopting intuitive processing, the perceived value of experiential purchases would be higher than materials. Namely, in promotional condition, the perceived value of experience would be higher than materials; while in preventive condition, the perceived value of material purchases would be higher than experience with the analytical processing style. Thus, we hypothesize the following,

H2: There will be an interaction effect of consumption type and message framing on perceived value. Experiential purchases will have a greater impact on consumers' perceived value in promotion condition $(\mathrm{H} 2 \mathrm{a})$, but less impact on consumers' perceived value in prevention condition than material purchases(H2b). 
H3: Perceived value will mediate the interaction effect of purchase type and message framing on purchase intention. Experiential purchases will have a greater impact on consumers' perceived value than material purchases in promotion condition, then choose experiential purchase in preference to material purchase(H3a); but less impact on consumers' perceived value in prevention condition, then choose material purchase in preference to experiential purchase $(\mathrm{H} 3 b)$.

\section{Study 1}

In this experiment, we probed (1) the interaction of purchase type and message framing on purchase intention and (2) the interaction of purchase type and message framing on perceived value and (3) perceived value's mediating effect on the interaction of purchase type and message framing on purchase intention.

\section{Method}

Participants. 188 participates were recruited from an online survey platform Wenjuanxing (www.wjx.cn, which provides functions equivalent to Amazon Mechanical Turk, Song, Jung, \& Zhang, 2021) in China (139 females, $M_{\text {age }}=21.84, S D_{\text {age }}=1.98$ ). When they finished all the questions, they would get 2 RMB (about .31 USD) for reward.

Procedure. In a 2(purchase type: material vs. experiential) $\times 2$ (message framing: promotion vs. prevention) participates-between design, participates were randomly assigned as follows: experiential-promotion $(n=$ 47), experiential-prevention ( $n=47)$, material-promotion $(n=48)$, and material-prevention $(n=46)$. First, participants read the descriptions of consumption situation and wrote down their feelings. Then, the definitions of material purchase and experiential purchase developed by Van Boven and Gilovich (2003) were presented to them and they were asked to rate the purchase from 1 (completely material purchase) -7 (completely experiential purchase) as the manipulation check of purchase type. They should choose what the situation described from the option of "the benefits of making the purchase," "the harm of missing the consumption" or "unclear" as the manipulation check of message framing. Next, they rated perceived value, purchase intention, and covariates such as involvement, materialism, experiential buying tendency, hedonic value of consumption, and demographic information (The instructions of Study 1 are provided in Appendix).

\section{Measures}

Purchase intention. We adapted the purchase intention scale used by Grewal et al. (1998) to measure the consumption intention of consumer. It consisted of 3 items, and participants responded on a 7-point Likert scale ranging from 1 (low) to 7 ( high). The three items was "if I will make a purchase, the probability of making this kind of purchase is", "the probability that I would consider buying this product is", and "the likelihood that I would purchase this product is". Cronbach's alpha was 0.92 .

Perceived value. This study used the service value scale developed by Cronin Jr et al. (2000). It consisted of 2 items, and participants responded on a 9-point Likert scale ranging from 1 (low) to 9 ( high). The two 
items were "overall, the value of this facility's services to me is " and "compared to what I had to give up, the overall ability of this facility to satisfy my wants and needs are." Cronbach's alpha was 0.71 .

Materialism. This study adopted Material Value Scale compiled by Richins (2004) and it was translated into Chinese by Chen et al.(2014), consisting of eight items. Participants responded on a 5-point Likert scale ranging from 1 (Strongly Disagree) to 5 (Strongly Agree). Cronbach's alpha was 0.77 .

Experiential buying tendency. This study adopted three items of Experiential Buying Tendency Scale (EBTS) to measure the experiential buying tendency of consumers (Howell et al., 2012) such as "in general, when I have extra money I am likely to buy a life experience" Participants responded on a 7-point Likert scale ranging from 1 (Strongly Disagree) to 7 (Strongly Agree). Cronbach's alpha was 0.75 .

Involvement. This study adapted the personal involvement scale compiled by Zaichkowsky (1994). It contains two dimensions, that is cognitive involvement and emotional involvement. The scale consists of 10 items, such as "to me the product is important or unimportant". Participants responded on a 7-point Likert scale ranging from 1 (unimportant) to 7 (important). Cronbach's alpha was 0.95 .

\section{Results}

\section{Manipulation check}

The independent samples t-test showed that people rated experiential purchases significantly higher than material purchase on the experiential purchase manipulation check question $\left(M_{\text {experiential }}=6.16, M_{\text {material }}=\right.$ $\left.2.85, t_{(186)}=-15.82, p<.001\right)$. The independent chi-square test $\left(X_{(1)}^{2}=83.38, p<.001\right)$ showed that there were obviously more people choosing gain option than other options in promotion (gain) condition; meanwhile, there were obviously more people choosing loss option than other options in prevention (loss) condition $\left(\chi^{2}{ }_{(1)}=7.84, p<.01\right)$. Thus, both manipulations were effective.

\section{Correlations among measures and predicting purchase intention.}

Pearson correlation analysis was conducted with SPSS 21.0 software, and the results showed that perceived value was significantly positively associated with purchase intention $(r=.62, p<.001)$, Materialism $(r=.28, p<.001)$, and involvement $(r=.54, p<.001)$. Materialism was significantly positively related to experiential buying tendency $(r=.21, p<.01)$, involvement $(r=.26 p<.001)$, purchase intention $(r$ $=.24, p<.01)$. Experiential buying tendency positively related to the involvement $(r=.18, p<.05)$, and purchase intention $(r=.26, p<.001)$. The purchase intention was positively related to the involvement $(r=$ $.51, p<.001)$ (mean, standard deviation and correlation coefficients of variables are showed in Table 1$)$. 
Table 1

Mean, Standard Deviation and Correlation Coefficients in Study 1

\begin{tabular}{|c|c|c|c|c|c|c|c|c|c|c|c|}
\hline Variables & $M$ & $S D$ & 1 & 2 & 3 & 4 & 5 & 6 & 7 & 8 & 9 \\
\hline 1.gender & 1.74 & .44 & - & & & & & & & & \\
\hline 2.age & 21.84 & 1.98 & $-.17^{*}$ & - & & & & & & & \\
\hline $\begin{array}{l}\text { 3.purchase } \\
\text { type }\end{array}$ & 1.50 & .50 & .04 & -.05 & - & & & & & & \\
\hline $\begin{array}{l}\text { 4.message } \\
\text { framing }\end{array}$ & 1.49 & .50 & .13 & -.05 & .01 & - & & & & & \\
\hline $\begin{array}{l}\text { 5.perceived } \\
\text { value }\end{array}$ & 6.24 & 1.34 & .04 & .04 & -.09 & -.05 & (.71) & & & & \\
\hline 6.materialism & 3.43 & .53 & .07 & -.04 & -.12 & -.08 & $.28^{\star \star \star}$ & $(.77)$ & & & \\
\hline $\begin{array}{l}\text { 7.Experiential } \\
\text { buying } \\
\text { tendency }\end{array}$ & 4.84 & .89 & .07 & -.09 & -.06 & .09 & .11 & $.21^{* *}$ & $(.75)$ & & \\
\hline 8.involvement & 5.15 & 1.26 & .07 & -.00 & .00 & .01 & $.54^{\star \star \star}$ & $.26^{\star \star \star}$ & $.18^{*}$ & $(.95)$ & \\
\hline $\begin{array}{l}\text { 9.purchase } \\
\text { intention }\end{array}$ & 4.78 & 1.26 & .02 & .07 & -.12 & .05 & $.62^{\star \star \star}$ & $.24^{\star \star}$ & $.26^{\star \star \star}$ & $.51^{\star \star \star}$ & $(.92)$ \\
\hline \multicolumn{12}{|c|}{ 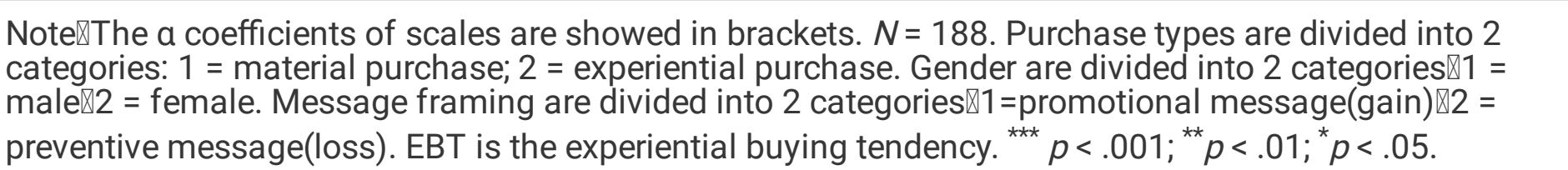 } \\
\hline
\end{tabular}

The interaction effect of purchase type and message framing on purchase intention

Hypothesis 1 predicted the interaction of purchase type and message framing was positively related to purchase intention. To test $\mathrm{H} 1$, we conducted a 2 (purchase type: experiential purchase vs. material purchase) $\times 2$ (message framing: promotion versus prevention) ANOVA on purchase intention by controlling materialism, experiential buying tendency, involvement, such as to this consumption, sex, age, family income, job, hedonic value and attraction of consumption. The results showed that the effect of purchase type on purchase intention $\left(\mathrm{F}_{(1,174)}=2.94, \mathrm{~ns}\right)$ was nonsignificant; nor the effect of message framing on purchase intention $\left(\mathrm{F}_{(1,174)}=.70, \mathrm{~ns}\right)$ or the interaction of purchase type and message framing on purchase intention was significant $\left(\mathrm{F}_{(1,174)}=.06, \mathrm{~ns}\right)$. Thus, $\mathrm{H} 1$ was not supported.

The interaction effect of purchase type and message framing on perceived value

Hypothesis 2 predicted the interaction of purchase type and message framing positively related to perceived value. To test $\mathrm{H} 2$, we conducted a 2 (purchase type: experiential purchase vs. material purchase) $\times 2$ (message framing: promotion versus prevention) ANOVA on perceived value by controlling materialism, experiential buying tendency, involvement, such as to this consumption, sex, age, family income, job, 
hedonic value and attraction of consumption. The results showed that nor the main effect of purchase type on perceived value $\left(F_{(1,174)}=1.13, n s\right)$ or the main effect of message framing on perceived value $\left(F_{(1,174)}=\right.$ $.87, \mathrm{~ns})$ was significant. However, the interaction of purchase type and message framing was significant $\left(F_{(1,174)}=4.04, p<.05, \eta_{p}^{2}=.02\right), H 2$ was supported. A simple effect test showed that in prevention condition, the perceived value of material purchase was significantly higher than the experiential purchase $\left(M_{\text {experiential }}=6.03, M_{\text {material }}=6.32, F_{(1,174)}=4.81, p<.05, \eta_{p}{ }^{2}=.03\right)$, thus $\mathrm{H} 2 \mathrm{~b}$ was supported. While in promotion condition, the difference in perceived value between experiential purchase and material purchase was nonsignificant $\left(M_{\text {experiential }}=6.20, M_{\text {material }}=6.40, F_{(1,174)}=.49, n s\right)$, thus $\mathrm{H} 2 \mathrm{a}$ was not supported. (see figure 1).

\section{Moderated mediation}

H3 predicted perceived value mediated the influence of interaction of purchase type and message framing on purchase intention. We conducted a moderated mediation test (PROCESS, model 7) after the centralization of purchase type and message framing and controlling materialism, experiential buying tendency, involvement, such as to this consumption, sex, age, family income, job, hedonic value and attraction of consumption. The results showed that (see Table 2) message framing moderated the effect of purchase type on perceived value $(B=-.64, S E=.32, p<.05)$, and perceived value significantly mediated the relationship of purchase type with purchase intention $(B=.36, S E=.07, p<.001)$. Bootstrap test with 5000 times showed that the mediating effect was moderated by message framing. On promotion condition $(-1 S D)$, the mediation was nonsignificant and the $95 \% \mathrm{Cl}$ was $[-.11, .24]$, including 0 . So the indirect effect of purchase type on purchase intention was nonsignificant. However, when consumers purchased under prevention condition $(+1 S D)$, perceived value significantly mediated the relationship of purchase type with purchase intention and the $95 \% \mathrm{Cl}$ was [-.36, -.03], excluding 0 , and the indirect effect of purchase type on purchase intention was significant. Thus, $\mathrm{H} 3$ was supported. 
Table 2

Moderated Mediation in Study 1

\begin{tabular}{|c|c|c|c|c|c|c|c|c|}
\hline \multicolumn{2}{|c|}{ Regression $(N=188)$} & \multicolumn{3}{|c|}{ Fitting Index } & \multicolumn{4}{|c|}{ Coefficient Significance } \\
\hline \multirow{2}{*}{$\begin{array}{l}\text { Outcome } \\
\text { Variables }\end{array}$} & Predictors & $R$ & $R^{2}$ & $F$ & $B$ & Bootstrap & Bootstrap & $T$ \\
\hline & & & & & & LLCl & ULCI & \\
\hline \multirow{4}{*}{$\begin{array}{l}\text { Perceived } \\
\text { value }\end{array}$} & & .65 & .43 & $10.02^{\star \star \star}(13)$ & & & & \\
\hline & Purchase type & & & & -.16 & -.47 & .15 & -1.04 \\
\hline & $\begin{array}{l}\text { Message } \\
\text { framing }\end{array}$ & & & & -.15 & -.46 & .16 & -.93 \\
\hline & $\begin{array}{l}\text { Purchase type } \times \\
\text { Message } \\
\text { framing }\end{array}$ & & & & -.64 & -1.28 & -.01 & $-2.01^{*}$ \\
\hline \multirow[t]{3}{*}{$\begin{array}{l}\text { Purchase } \\
\text { intention }\end{array}$} & & .71 & .51 & $14.88^{\star \star \star}(12)$ & & & & \\
\hline & Purchase type & & & & -.19 & -.46 & .08 & -1.39 \\
\hline & Perceived value & & & & .36 & .23 & .49 & $5.55^{\star \star \star}$ \\
\hline
\end{tabular}

\section{Study 2}

Study 2 was designed to replicate the findings of Study 1 by modifying the manipulation of experiential purchase and material purchase. We manipulated the purchase type by emphasizing the experiential or material nature of the same consumption (wireless headphones).

\section{Method}

Participants. One hundred ninety two participates were recruited from China online platform "wxj"(142 females, $M_{\text {age }}=21.16, S D_{\text {age }}=2.22$ ). When they finished all the questions, they would get 2 RMB (about .31 USD) for reward.

Procedure. In a 2(purchase type: material vs. experiential) $\times 2$ (message framing: promotion vs. prevention) participates-between design, participates were randomly assigned as follows: experiential-promotion ( $n=$ 50), experiential-prevention ( $n=48)$, material-promotion $(n=39)$, and material-prevention $(n=55)$. First, the definitions of material purchases and experiential purchase developed by Van Boven and Gilovich (2003) were presented to them and they were asked to categorize 6 kinds of consumption with different motivations into experiential or material purchases. Then, participants read the descriptions of consumption situation and wrote down their feelings, and rate the purchase from 1 (completely material purchase)-7(completely experiential purchase) as the manipulation check of purchase type. Meanwhile, 
they must rate what the situation described from 1 (completely the benefits of making the purchase) -7 (completely the harm of missing the purchase) as the manipulation check of message framing. Next, they rated purchase intention, perceived value, and covariates such as involvement, materialism, experiential buying tendency, hedonic value and practical value of consumption, the understanding and fluentness of the posters, posters' description style (emotional or rational) and demographic information (The instructions of Study 2 are provided in Appendix).

\section{Measures}

Perceived value. Study 1 chose concert as experiential purchase and wireless headphones as material purchase. The former was intangible, and the latter was tangible. When comparing the perceived value of the two purchases, it's better to compare the overall service value. So we adopted the service value scale used by Cronin Jr et al. (2000) in Study 1. However, we manipulated the purchase type by emphasizing the experiential or material nature of wireless headphones, which were tangible in Study 2, and it's better to compare the perceived value from different dimensions. So, we adopted the shorter vision of the consumerperceived value scale compiled by Sweeney and Soutar (2001) and developed by Walsh et al. (2014). It contains four dimensions, such as social value, emotional value, functional value (performance/ quality) and functional value (price/value for money). The scale consisted of 8 items, such as "has consistent quality," and "would make me feel good", and participants responded on a 7-point Likert scale ranging from 1 (strongly disagree) to 7 (strongly agree). Cronbach's alpha was 0.92 .

The scales of purchase intention, materialism, experiential buying tendency were the same scales used in Study 1.

\section{Results}

\section{Manipulation check}

The independent samples t-test showed people rated experiential purchases significantly higher than material purchase on the purchase type manipulation check question $\left(M_{\text {experiential }}=5.56, M_{\text {material }}=3.09\right.$, $\left.t_{(190)}=-10.04, p<.001\right)$. And people rated more harm of preventive message(loss) than promotional message(gain) on the message framing manipulation check question $\left(M_{\text {promotion }}=5.56, M_{\text {prevention }}=3.09\right.$, $\left.t_{(150.01)}=-9.96, p<.001\right)$. Thus, the manipulations were successful.

\section{Correlations among measures and predicting purchase intention.}

Pearson correlation analysis was conducted with SPSS 21.0 software, and the results showed perceived value was significantly positively associated with purchase intention $(r=.75, p<.001)$, purchase type $(r=$ $.15, p<.05)$, Materialism $(r=.17, p<.05)$, and involvement $(r=.64, p<.001)$. Materialism was significantly positively related to experiential buying tendency $(r=.15, p<.05)$, purchase intention $(r=.18, p<.05)$, and gender $(r=.15, p<.05)$. The purchase intention positively related to the involvement $(r=.59, p<.001)$. (mean, standard deviation and correlation coefficients of variables are showed in Table 3 ). 
Table 3

Mean, Standard Deviation and Correlation Coefficients in Study 2

\begin{tabular}{|c|c|c|c|c|c|c|c|c|c|c|c|}
\hline Variables & $M$ & SD & 1 & 2 & 3 & 4 & 5 & 6 & 7 & 8 & 9 \\
\hline 1.gender & 1.74 & .44 & - & & & & & & & & \\
\hline 2.age & 21.16 & 2.22 & $-.18^{*}$ & - & & & & & & & \\
\hline $\begin{array}{l}\text { 3.purchase } \\
\text { type }\end{array}$ & 1.51 & .50 & .11 & -.11 & - & & & & & & \\
\hline $\begin{array}{l}\text { 4.message } \\
\text { framing }\end{array}$ & 1.54 & .50 & .17 & $-.05^{*}$ & -.10 & - & & & & & \\
\hline $\begin{array}{l}\text { 5.perceived } \\
\text { value }\end{array}$ & 4.48 & 1.11 & -.07 & .05 & $.15^{*}$ & -.10 & $(.92)$ & & & & \\
\hline 6.materialism & 3.50 & .59 & $.15^{*}$ & -.08 & .01 & -.08 & $.17^{*}$ & $(.79)$ & & & \\
\hline 7.EBT & 5.09 & 1.03 & .02 & .01 & .03 & .09 & .13 & $.15^{*}$ & $(.80)$ & & \\
\hline 8.involvement & 4.74 & 1.31 & .01 & .05 & .13 & -.07 & $.64^{\star \star \star}$ & .08 & .12 & $(.95)$ & \\
\hline $\begin{array}{l}\text { 9.purchase } \\
\text { intention }\end{array}$ & 4.72 & 1.34 & -.02 & .04 & $.25^{\star \star \star}$ & -.01 & $.75^{\star \star \star}$ & $.18^{\star}$ & .10 & $.59^{\star \star \star}$ & $(.93)$ \\
\hline \multicolumn{12}{|c|}{ 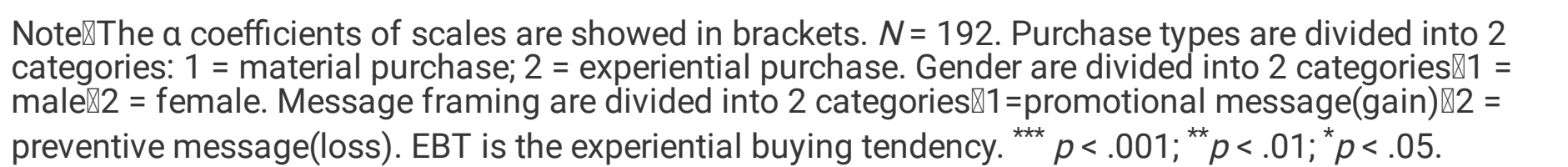 } \\
\hline
\end{tabular}

The interaction effect of purchase type and message framing on purchase intention

Hypothesis 1 predicted the interaction of purchase type and message framing positively related to purchase intention. To test $\mathrm{H} 1$, we conducted a 2 (purchase type: experiential purchase vs. material purchase) $\times 2$ (message framing: promotion versus prevention) ANOVA on purchase intention by controlling materialism, experiential buying tendency, involvement, sex, age, family income, job, hedonic value and practical value of consumption, posters' description style, the understanding and fluentness of the posters. Then found that the effect of purchase type on purchase intention $\left(M_{\text {experiential }}=4.91, M_{\text {material }}=4.51, F_{(1,176)}=7.90, p<.01\right.$, $\left.\eta_{p}^{2}=.04\right)$ was significant; nor the effect of message framing on purchase intention $\left(F_{(1,176)}=1.01, n s\right)$ or the interaction of purchase type and message framing on purchase intention was significant $\left(F_{(1,176)}=.23, n s\right)$. Thus, $\mathrm{H} 1$ was not supported.

The interaction effect of purchase type and message framing on perceived value

Hypothesis 2 predicted the interaction of purchase type and message framing positively related to perceived value. To test $\mathrm{H} 2$, we conducted a 2 (purchase type: experiential purchase vs. material purchase) $\times 2$ (message framing: promotion versus prevention) ANOVA on perceived value by controlling materialism, experiential buying tendency, involvement, sex, age, family income, job, hedonic value and practical value of 
consumption, posters' description style, the understanding and fluentness of the posters. Then found that nor the effect of purchase type on perceived value $\left(F_{(1,176)}=.80, n s\right)$ or the effect of message framing on perceived value $\left(\mathrm{F}_{(1,176)}=.52\right.$, ns) was significant. However, the analysis of ANOVA yielded an interaction $\left(F_{(1,176)}=4.46, p<.05, \eta_{p}{ }^{2}=.03\right)$. A simple effect test showed that in promotion condition, the perceived value of experiential purchase was significantly higher than the material purchase $\left(M_{\text {experiential }}=\right.$ $\left.4.92, M_{\text {material }}=4,16, F_{(1,176)}=4.12, p<.05, \eta_{p}^{2}=.02\right)$; while in prevention condition, the difference in perceived value between experiential purchase and material purchase was nonsignificant $\left(M_{\text {experiential }}=\right.$ $\left.4.35, M_{\text {material }}=4.41, F_{(1,176)}=.79, n s\right)$, thus $\mathrm{H} 2$ was supported. (see figure 3 ).

\section{Moderated mediation}

$\mathrm{H} 2$ predicted perceived value mediated the influence of interaction of purchase type and message framing on purchase intention. We conducted a moderated mediation test (PROCESS, model 7) after the centralization of purchase type and message framing and controlling materialism, experiential buying tendency, involvement, sex, age, family income, job, hedonic value and practical value of consumption, posters' description style, understanding and fluentness of the posters. The results showed that (see Table 4) message framing moderated the effect of purchase type on perceived value $(B=-.49, S E=.23, p<.05)$, and perceived value significantly mediated the relationship of purchase type with purchase intention $(B=$ $.63, \mathrm{SE}=.08, \mathrm{p}<.001)$. Bootstrap test with 5000 times showed that the mediating effect was moderated by message framing. On prevention conditions (+1SD), the mediation was nonsignificant and the $95 \% \mathrm{Cl}$ was $[-.33, .09]$, including 0 . So the indirect effect of purchase type on purchase intention was nonsignificant. However, when consumers purchased under promotion condition (-1SD), perceived value significantly mediated the relationship of purchase type with purchase intention and the $95 \% \mathrm{Cl}$ was [.00, .45], excluding 0 , and the indirect effect of purchase type on purchase intention was significant. Thus, $\mathrm{H} 2$ was supported. 
Table 4

Moderated Mediation in Study 2

\begin{tabular}{|c|c|c|c|c|c|c|c|c|}
\hline \multicolumn{2}{|c|}{ Regression $(N=192)$} & \multicolumn{3}{|c|}{ Fitting Index } & \multicolumn{4}{|c|}{ Coefficient Significance } \\
\hline \multirow{2}{*}{$\begin{array}{l}\text { Outcome } \\
\text { Variables }\end{array}$} & Predictors & $R$ & $R^{2}$ & $F$ & $B$ & Bootstrap & Bootstrap & $T$ \\
\hline & & & & & & LLCl & ULCl & \\
\hline \multirow{4}{*}{$\begin{array}{l}\text { Perceived } \\
\text { value }\end{array}$} & & .74 & .55 & $14.06^{\star \star *}(15)$ & & & & \\
\hline & Purchase type & & & & .09 & -.14 & .32 & .74 \\
\hline & $\begin{array}{l}\text { Message } \\
\text { framing }\end{array}$ & & & & -.09 & -.32 & .14 & -.77 \\
\hline & $\begin{array}{l}\text { Purchase type } \times \\
\text { Message } \\
\text { framing }\end{array}$ & & & & -.49 & -.94 & -.03 & $-2.11^{*}$ \\
\hline \multirow[t]{3}{*}{$\begin{array}{l}\text { Purchase } \\
\text { intention }\end{array}$} & & .82 & .67 & $25.59^{\star \star \star}(14)$ & & & & \\
\hline & Purchase type & & & & .33 & .10 & .57 & $2.77^{\star \star}$ \\
\hline & Perceived value & & & & .63 & .48 & .78 & $8.21^{\star \star \star}$ \\
\hline
\end{tabular}

\section{Discussion}

This research explored the interaction of purchase type and message framing on purchase intention, as well as the underlying mechanism by two experiments. It is found that purchase type and message framing affect the perceived value together, and the interaction between them indirectly affects consumer purchase intention through perceived value. However, the interaction effect of consumption type and message framing on purchase intention is nonsignificant in Study 1 and Study 1 . It further supports the role of predictor of perceived value in the purchase intention. When deciding on what to buy, people will evaluate the value of products at first, and then to choose the most valuable product based on the principle of value maximization. The result shows perceived value is an important predictor of consumers' purchase intention, which supports the previous finding that perceived value plays an important role in consumption decision making (Lu \& Hsiao, 2010; Hong et al., 2017; Mencarelli \& Lombart, 2017).

In both studies, there is no difference in perceived value of material purchases between preventive and promotional messages, however the perceived value of experiential purchases has a greater impact on promotional messages than preventive messages. This might be caused by the processing style of thinking when consumers make decisions. Results find both intuition and rationality can play important roles in this strategic decision making (Calabretta, Gemser, \& Wijnberg,2017).When selecting objects in the material purchases, consumers are using analytical processing and will pay attention to the message no matter it is preventive or promotional, which makes them especially insensitive to framing effects(McElroy \& Seta, 
2003). However, when selecting experiential purchases, individuals depend more on intuition, adopting heuristic processing and are more sensitive to framing effects (McElroy \& Seta, 2003). Furthermore, if we push them to prevention information and force them to think about the loss of missing experiential purchase rationally, the appeal of experiential buying might decrease, which lead to low perceived value. That's why the perceived value of experiential purchases has a greater impact on promotional messages than preventive messages.

Compared to materials, consumer purchase intention of experience is higher in Study 2. In this study, we manipulate the purchase type by emphasizing the experiential or material nature of wireless headphones. Wireless headphones are objects, describing them as experiential purchase would not weaken its physical properties, but increase its experiential charm. The result also suggests that describing objects to experiential purchase would be more attractive than material purchase. In Study 1, the result shows that material purchases have a greater impact on consumers' perceived value than experiential purchases in prevention condition. Additionally, the result of study 2 shows experiential purchases have a greater impact on consumers' perceived value than material purchases in the promotion condition. As mentioned in the front, experiential purchases are made for experience, which is intangible, and they are evaluated by intuition mostly; while material purchases are made for possessing, they are tangible objects, which are evaluated on reason mostly(Guo et al., 2017). When advertising the consumption with promotional information, people will act as "cognitive misers" and tend to process the message intuitively at first (Sun et al., 2007). In this condition, consumer decides on intuition, and they will evaluate experiential purchase with higher perceived value than material purchases. However, when advertising consumption with preventive information, people will evaluate the losses carefully and decide on reason for the inclination of loss aversion (Tversky \& Kahneman, 1992). In this condition, they will evaluate material with higher perceived value than experiential purchases, cause material purchases are more tangible than experiential purchase, which made them easier to be evaluated objectively. This further supports our hypothesis, in general, describing experiential purchases (material purchases) in loss or gain will have a different advertising effect.

By examining how purchase type and message-framing influence purchase intention, stores could find a suitable way to advertise different kinds of consumption. The suggestions of the current study focus on two points:

First, it's better to advertise the benefits of experiential purchase rather than regrets, such as travel, theme parks, and so on. Merchants should try to awake consumers' imagination about the experience, which will greatly promote the purchase intention of consumers. As for goods, stores should choose another way to promotion, emphasizing the regrets of missing them. This can be combined with strategies of promotion, such as limited time and quantity. Second, it's a good way to depict the goods as experiential purchases, that is try emphasizing the experience brought by the objects, which will increase the attractiveness of material purchases and further enhance the purchase intention of people.

In this study, it is assumed that people choose experiential purchases more rely on intuition and choose material purchase more rely on rationality. And preventive information priming on consumers' intuitive style 
of thinking, while promotional information priming on consumers' analytical style of thinking. Future research may conduct experiments to explore the specific processing styles in the different conditions further. Nowadays, stores often hold some promotional activities to promote impulsive consumption of consumers by arousing the regrets of missing opportunities. Regret is another important factor to affect purchase intention(Sandberg \& Conner, 2008). Emphasizing the loss of missing the consumption in preventive condition might arouse the regret of consumer. The regret and perceived value might affect the purchase intention together. So, whether purchase type and message framing will affect consumers' regret, and whether it will further affect consumers' purchase intention are still need to be explored.

\section{Declarations}

\section{DATA AVAILABILITY}

The datasets generated during and/or analyzed during the current study are available from the corresponding author on reasonable request.

\section{INFORMED CONSENT}

Informed consent was obtained from all individual participants included in the study.

\section{Statements and Declarations}

All procedures performed in studies involving human participants were in accordance with the ethical standards of the institutional research committee and with the 1964 Helsinki Declaration and its later amendments or comparable ethical standard. The authors also declare that they have no confict of interest.

\section{Acknowledgements}

This work was supported by the National Natural Science Fund of China (NSFC)(grant number:71601084, 71971099, 71772077), Foundation of Institute for Enterprise Development, Jinan University, Guangdong Province (grant number: 2021MYZD01), Jinan University Management School Funding Program (grant numbers: GY21011), Foundation of Research Instituteon Brand Innovation and Development of Guangzhou(2021CR03). The funding source had no such involvement during conducting this research.

\section{References}

1. Aknin, L.B., Wiwad, D., and Hanniball, K.B. (2018). Buying well-being: Spending behavior and happiness. Social Personality Psychology Compass 12(5), e12386. doi: 10.1111/spc3.12386.

2. Amatulli, C., De Angelis, M., Peluso, A.M., Soscia, I., and Guido, G. (2019). The effect of negative message framing on green consumption: An investigation of the role of shame. Journal of Business Ethics 157(4), 1111-1132. doi: 10.1007/s10551-017-3644-x.

3. Baek, T.H., and Yoon, S. (2017). Guilt and shame: Environmental message framing effects. Journal of Advertising 46(3), 440-453. doi: 10.1080/00913367.2017.1321069. 
4. Banerjee, B., and Bandyopadhyay, S. (2003). Advertising competition under consumer inertia. Marketing Science 22(1), 131-144. doi: 10.1287/mksc.22.1.131.12843.

5. Caprariello, P.A., and Reis, H.T. (2013). To do, to have, or to share? Valuing experiences over material possessions depends on the involvement of others. Journal of Personality and Social Psychology 104(2), 199-215. doi: 10.1037/a0030953.

6. Carter, T.J., and Gilovich, T. (2014). "Getting the most for the money: The hedonic return on experiential and material purchases," in consumption and well-being in the material world. (Dordrecht: Springer), 49-62.

7. Chen, S.F.S., Monroe, K.B., and Lou, Y.C. (1998). The effects of framing price promotion messages on consumers' perceptions and purchase intentions. Journal of Retailing 74(3), 353-372. doi: 10.1016/S0022-4359(99)80100-6.

8. Cronin Jr, J.J., Brady, M.K., and Hult, G.T.M. (2000). Assessing the effects of quality, value, and customer satisfaction on consumer behavioral intentions in service environments. Journal of Retailing 76(2), 193-218. doi: 10.1016/S0022-4359(00)00028-2.

9. Dehghani, M., and Tumer, M. (2015). A research on effectiveness of Facebook advertising on enhancing purchase intention of consumers. Computers in Human Behavior 49, 597-600. doi: 10.1016/j.chb.2015.03.051.

10. Duan, J., and Dholakia, R.R. (2018). How purchase type influences consumption-related posting behavior on social media: The moderating role of materialism. Journal of Internet Commerce 17(1), 6480. doi: 10.1080/15332861.2018.1424396.

11. Gallagher, K.M., and Updegraff, J.A. (2012). Health message framing effects on attitudes, intentions, and behavior: A meta-analytic review. Annals of Behavioral Medicine 43(1), 101-116. doi: 10.1007/s12160-011-9308-7.

12. Gallo, I., Sood, S., Mann, T.C., and Gilovich, T. (2017). The heart and the head: On choosing experiences intuitively and possessions deliberatively. Journal of Behavioral Decision Making 30(3), 754-768. doi: 10.1002/bdm.1997.

13. Gamliel, E., and Herstein, R. (2007). The effect of framing on willingness to buy private brands. Journal of Consumer Marketing 24(6), 334-339. doi: 10.1108/07363760710822918.

14. Gannon, M., Taheri, B., and Olya, H. (2019). Festival quality, self-connection, and bragging. Annals of Tourism Research 76, 239-252. doi: 10.1016/j.annals.2019.04.014.

15. Gilovich, T., Kumar, A., and Jampol, L. (2015). A wonderful life: Experiential consumption and the pursuit of happiness. Journal of Consumer Psychology 25(1), 152-165. doi: 10.1016/j.jcps.2014.08.004.

16. Gilovich, T., and Gallo, I. (2020). Consumers' pursuit of material and experiential purchases: A review. Consumer Psychology Review, 3(1), 20-33.doi: 10.1002/arcp.1053

17. Grewal, D., Monroe, K.B., and Krishnan, R. (1998). The effects of price-comparison advertising on buyers' perceptions of acquisition value, transaction value, and behavioral intentions. Journal of Marketing 62(2), 46-59. doi: 10.1177/002224299806200204. 
18. Guo, L., Trueblood, J.S., and Diederich, A. (2017). Thinking fast increases framing effects in risky decision making. Psychological Science 28(4), 530-543. doi: 10.1177/0956797616689092.

19. Hong, J.C., Lin, P.H., and Hsieh, P.C. (2017). The effect of consumer innovativeness on perceived value and continuance intention to use smartwatch. Computers in Human Behavior 67, 264-272. doi: 10.1016/j.chb.2016.11.001.

20. Howell, R.T., and Hill, G. (2009). The mediators of experiential purchases: Determining the impact of psychological needs satisfaction and social comparison. The Journal of Positive Psychology 4(6), 511522. doi: 10.1080/17439760903270993.

21. Howell, R.T., Pchelin, P., and lyer, R. (2012). The preference for experiences over possessions: Measurement and construct validation of the Experiential Buying Tendency Scale. The Journal of Positive Psychology 7(1), 57-71. doi: 10.1080/17439760.2011.626791.

22. Hwang, E., Kim, J., Lee, J.C., and Kim, S. (2019). To do or to have, now or later, in travel: Consumption order preference of material and experiential travel activities. Journal of Travel Research 58(6), 961976. doi: 10.1177/0047287518790416.

23. Inbar, Y., Cone, J., and Gilovich, T. (2010). People's intuitions about intuitive insight and intuitive choice. Journal of Personality and Social Psychology 99(2), 232-247. doi: 10.1037/a0020215.

24. Konuk, F.A. (2018). The role of store image, perceived quality, trust and perceived value in predicting consumers' purchase intentions towards organic private label food. Journal of Retailing and Consumer Services 43, 304-310. doi: 10.1016/j.jretconser.2018.04.011.

25. Kumar, A., \& Gilovich, T. (2016). To do or to have, now or later? The preferred consumption profiles of material and experiential purchases. Journal of Consumer Psychology, 26(2), 169-178.

26. Kumar, A., Killingsworth, M.A., and Gilovich, T. (2014). Waiting for Merlot: Anticipatory consumption of experiential and material purchases. Psychological science 25(10), 1924-1931.

27. Kuo, Y.F., Wu, C.M., and Deng, W.J. (2009). The relationships among service quality, perceived value, customer satisfaction, and post-purchase intention in mobile value-added services. Computers in Human Behavior 25(4), 887-896. doi: 10.1016/j.chb.2009.03.003.

28. Lagomarsino, M., Lemarié, L., and Puntiroli, M. (2020). When saving the planet is worth more than avoiding destruction. The importance of message framing when speaking to egoistic individuals. Journal of Business Research 118, 162-176. doi: 10.1016/j.jbusres.2020.06.046.

29. Lin, R. (2018). Silver lining of envy on social media? The relationships between post content, envy type, and purchase intentions. Internet Research 28(4), 1142-1164. doi: 10.1108/IntR-05-2017-0203.

30. Lin, R., Van De Ven, N., and Utz, S. (2018). What triggers envy on social network sites? a comparison between shared experiential and material purchases. Computers in Human Behavior 85, 271-281. doi: 10.1016/j.chb.2018.03.049.

31. Lu, H.P., and Hsiao, K.L. (2010). The influence of extro/introversion on the intention to pay for social networking sites. Information \& Management 47(3), 150-157. doi: 10.1016/j.im.2010.01.003.

32. Maheswaran, D., and Meyers Levy, J. (1990). The influence of message framing and issue involvement. Journal of Marketing Research 27(3), 361-367. doi: 10.1177/002224379002700310. 
33. Mann, T.C., and Gilovich, T. (2016). The asymmetric connection between money and material vs. experiential purchases. The Journal of Positive Psychology 11(6), 647-658. doi:

10.1080/17439760.2016.1152594.

34. Martins, J., Costa, C., Oliveira, T., Gonçalves, R., and Branco, F. (2019). How smartphone advertising influences consumers' purchase intention. Journal of Business Research 94, 378-387. doi: 10.1016/j.jbusres.2017.12.047.

35. McElroy, T., and Seta, J.J. (2003). Framing effects: An analytic-holistic perspective. Journal of Experimental Social Psychology 39(6), 610-617. doi: 10.1016/S0022-1031(03)00036-2.

36. Mencarelli, R., and Lombart, C. (2017). Influences of the perceived value on actual repurchasing behavior: Empirical exploration in a retailing context. Journal of Retailing and Consumer Services 38, 12-21. doi: 10.1016/j.jretconser.2017.04.008.

37. Meyerowitz, B.E., and Chaiken, S. (1987a). The effect of message framing on breast self-examination attitudes, intentions, and behavior. Journal of Personality and Social Psychology 52(3), 500-510. doi: 10.1037/0022-3514.52.3.500.

38. Meyerowitz, B.E., and Chaiken, S. (1987b). The effect of message framing on breast self-examination attitudes, intentions, and behavior. Journal of Personality and Social Psychology 52(3), 500-510. doi: 10.1037/0022-3514.52.3.500.

39. Pandža Bajs, I. (2015). Tourist perceived value, relationship to satisfaction, and behavioral intentions: The example of the Croatian tourist destination Dubrovnik. Journal of Travel Research 54(1), 122-134. doi: $10.1177 / 0047287513513158$.

40. Richins, M.L. (2004). The material values scale: Measurement properties and development of a short form. Journal of Consumer Research 31(1), 209-219. doi: 10.1086/383436.

41. Sandberg, T., and Conner, M. (2008). Anticipated regret as an additional predictor in the theory of planned behaviour: A meta-analysis. British Journal of Social Psychology 47(4), 589-606. doi: 10.1348/014466607X258704.

42. Song, X., Jung, J., \& Zhang, Y. (2021). Consumers' preference for user-designed versus designerdesigned products: The moderating role of power distance belief. Journal of Marketing Research 58(1), 163-181. doi:10.1177/0022243720972702.

43. Sun, Y., Li, S., and Yin, X.I. (2007). Two systems in decision-making and reasoning: Heuristic system and analytic system. Advances in Psychological Science 15(5), 721-726.

44. Sweeney, J.C., and Soutar, G.N. (2001). Consumer perceived value: The development of a multiple item scale. Journal of Retailing 77(2), 203-220. doi: 10.1016/S0022-4359(01)00041-0.

45. Tam, J.L. (2004). Customer satisfaction, service quality and perceived value: An integrative model. Journal of Marketing Management 20(7-8), 897-917. doi: 10.1362/0267257041838719.

46. Tanford, S., Choi, C., and Joe, S.J. (2019). The influence of pricing strategies on willingness to pay for accommodations: Anchoring, framing, and metric compatibility. Journal of Travel Research 58(6), 932944. doi: $10.1177 / 0047287518793037$. 
47. Tully, S.M., and Sharma, E. (2017). Context-dependent drivers of discretionary debt decisions: explaining willingness to borrow for experiential purchases. Journal of Consumer Research 44(5), 960973. doi: $10.1093 / \mathrm{jcr} / \mathrm{ucx} 078$.

48. Tversky, A., and Kahneman, D. (1992). Advances in prospect theory: Cumulative representation of uncertainty. Journal of Risk and Uncertainty 5(4), 297-323. doi: 10.1007/BF00122574.

49. Ülkümen, G., and Thomas, M. (2013). Personal relevance and mental simulation amplify the duration framing effect. Journal of Marketing Research 50(2), 194-206. doi: 10.1509/jmr.10.0172.

50. Van Boven, L., and Gilovich, T. (2003). To do or to have? That is the question. Journal of Personality and Social Psychology 85(6), 1193-1202. doi: 10.1037/0022-3514.85.6.1193.

51. Van't Riet, J., Cox, A.D., Cox, D., Zimet, G.D., De Bruijn, G.J., Van den Putte, B., et al. (2016). Does perceived risk influence the effects of message framing? Revisiting the link between prospect theory and message framing. Health Psychology Review 10(4), 447-459. doi: 10.1080/17437199.2016.1176865.

52. Walsh, G., Shiu, E., and Hassan, L.M. (2014). Replicating, validating, and reducing the length of the consumer perceived value scale. Journal of Business Research 67(3), 260-267. doi: 10.1016/j.jbusres.2013.05.012.

53. Weingarten, E., \& Goodman, J. K. (2021). Re-examining the experiential advantage in consumption: A meta-analysis and review. Journal of Consumer Research, 47(6), 855-877.

54. Zaichkowsky, J.L. (1994). The personal involvement inventory: Reduction, revision, and application to advertising. Journal of Advertising 23(4), 59-70. doi: 10.1080/00913367.1943.10673459.

55. Zeithaml, V.A. (1988). Consumer perceptions of price, quality, and value: A means-end model and synthesis of evidence. Journal of Marketing 52(3), 2-22. doi: 10.1177/002224298805200302.

56. Zhang, M., Zhang, G.Y., Gursoy, D., and Fu, X.R. (2018). Message framing and regulatory focus effects on destination image formation. Tourism Management 69, 397-407. doi:

10.1016/j.tourman.2018.06.025.

57. Zhang, Y., and Buda, R. (1999). Moderating effects of need for cognition on responses to positively versus negatively framed advertising messages. Journal of Advertising 28(2), 1-15. doi: 10.1080/00913367.1999.10673580.

\section{Appendix}

Appendix is not available with this version.

\section{Figures}




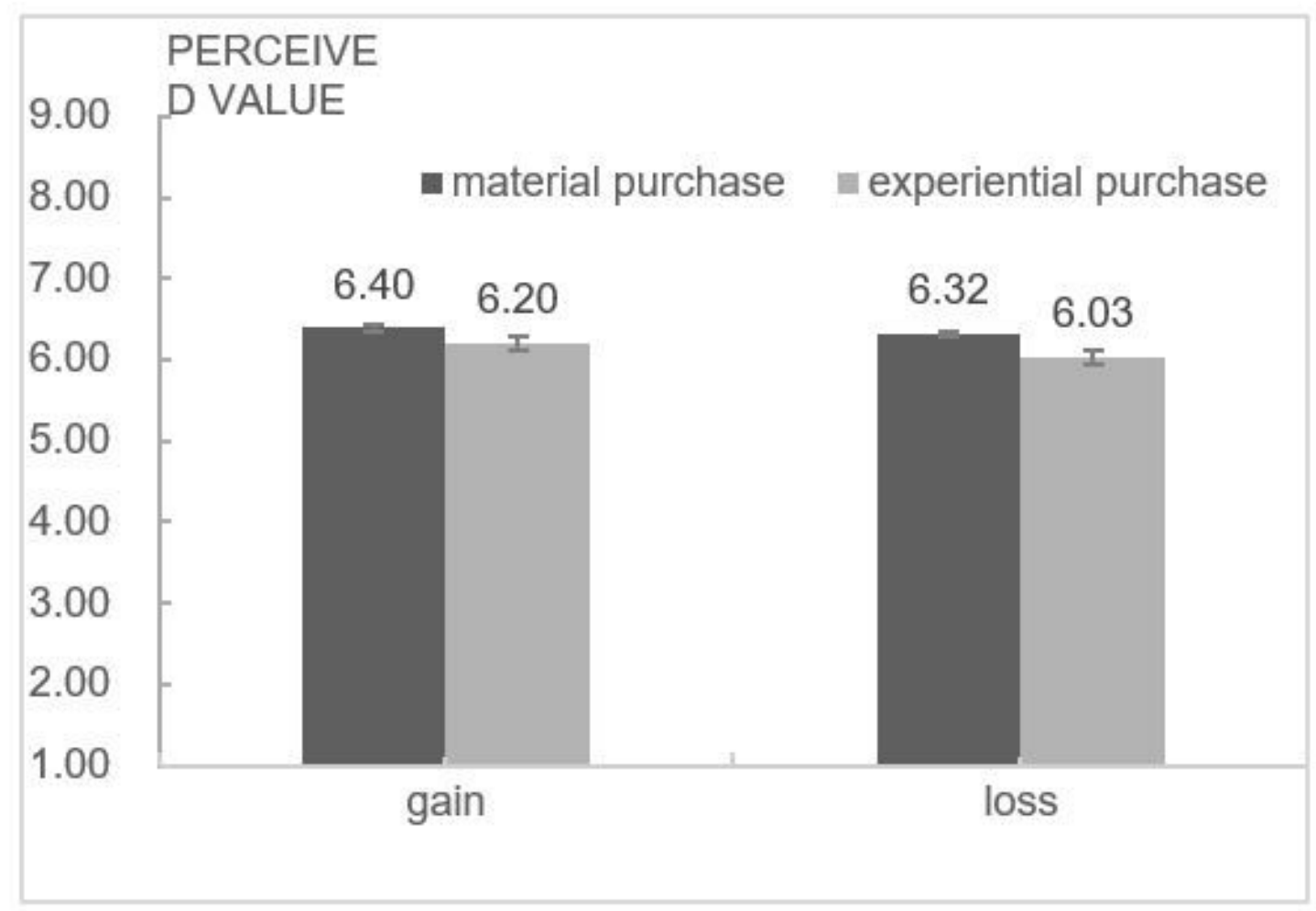

Figure 1

The interaction effect of purchase type and message framing on perceived value in Study 1

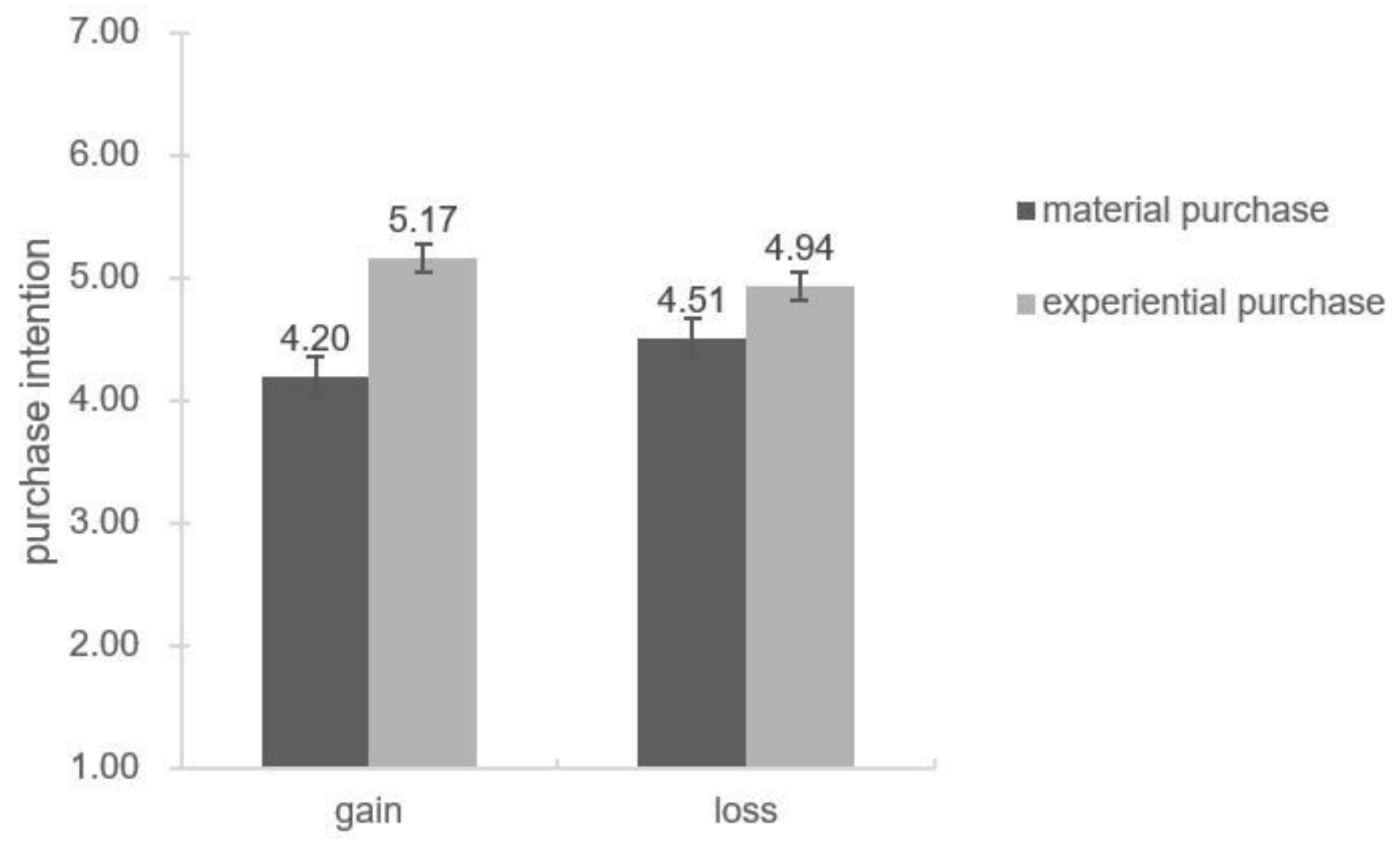




\section{Figure 2}

The interaction effect of purchase type and message framing on purchase intention in Study 2

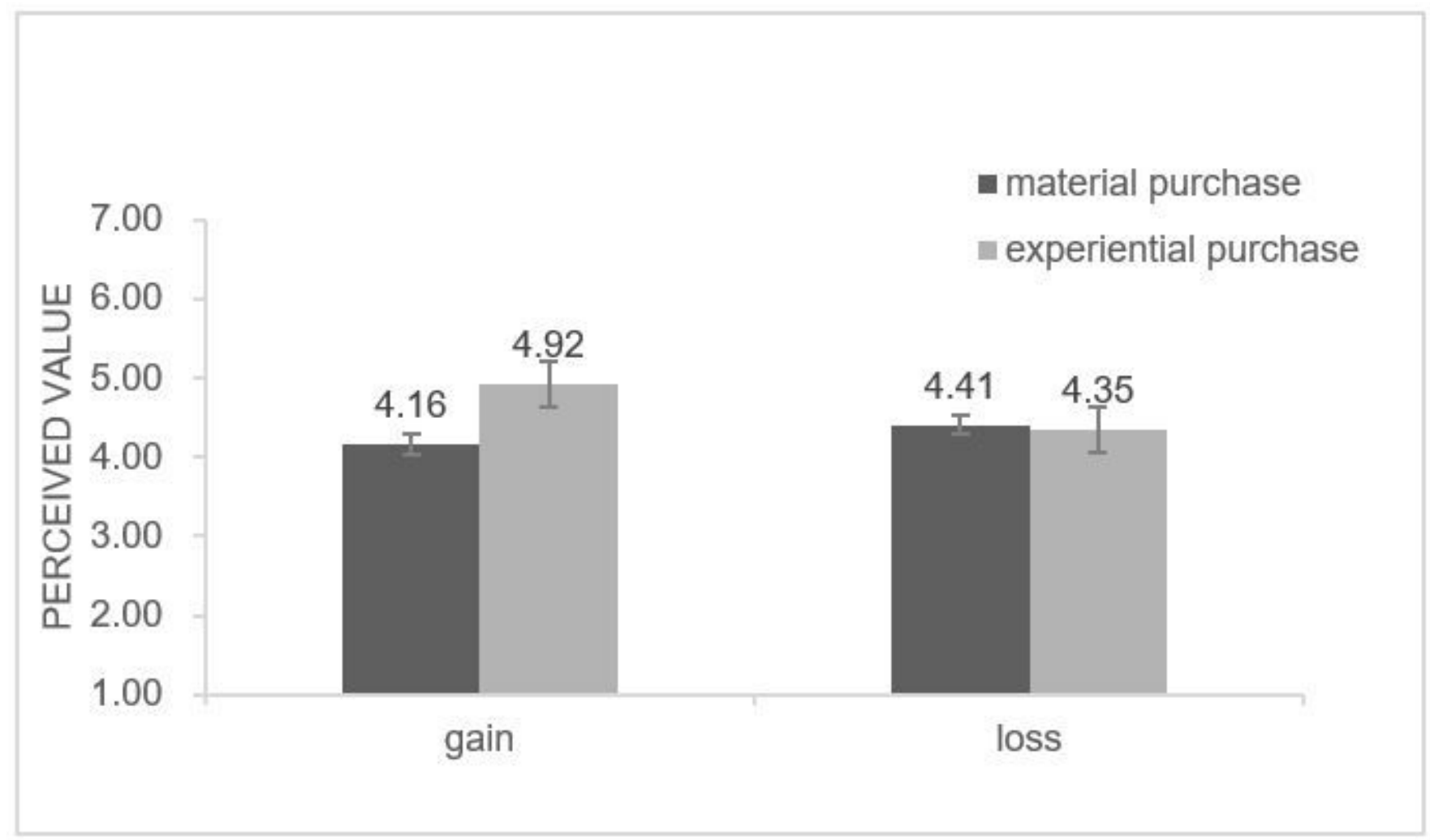

\section{Figure 3}

The interaction effect of purchase type and message framing on perceived value in Study 2 